\title{
Service Quality, Brand Attributes, Satisfaction and Loyalty of Guests Staying at Le Meridien Hotel Bali Jimbaran
}

\author{
Luh Putu Triyanti Ariestiana Dewi ${ }^{1 *}$, Agung Suryawan Wiranatha ${ }^{2}$, \\ I Gusti Ayu Oka Suryawardani \\ ${ }^{1}$ Master Program in Tourism, Udayana University \\ ${ }^{2}$ Centre of Excellence in Tourism, Udayana University \\ *Corresponding Author: luhpututriyanti@gmail.com \\ DOI: https://doi.org/10.24922/eot.v8i1.71451
}

\begin{abstract}
Article Info
Submitted

January $25^{\text {th }} 2021$

Accepted

March $18^{\text {th }} 2021$

Published

March $31^{\text {th }} 2021$
\end{abstract}

\begin{abstract}
Guest satisfaction and loyalty become an indicator of the success of a hotel. Service quality and brand attributes are two components that related the satisfaction and loyalty of guests who stay at the hotel. The purposes of this study were 1) To analyse the relationship of service quality and brand attributes to the satisfaction of guests staying at the Le Meridien Bali Jimbaran hotel, 2) To analyse the relationships of service quality and brand attributes to the loyalty of guests staying at the Le Meridien Bali Jimbaran hotel, 3) To analyse the satisfaction of the guests staying at the Le Meridien Bali Jimbaran hotel. This research used quantitative method involving 100 guests who stayed overnight as the respondents. Sampling was done by accidental sampling and analysis using Structural Equation Model (SEM) with SmartPLS 3.0 software. The results showed that 1) Service quality had a significant effect on satisfaction, 2) Service quality had no significant effect on loyalty, 3) Brand attributes had a significant effect on satisfaction, 4) Brand attributes had significant influence on loyalty, and 5) Satisfaction has a significant effect on loyalty. Suggestions that can be made in this study that hotel should support loyalty, maintain and pay close attention to brand attributes that need to be improved and guest mindset influence, as well as the should find other aspects that can support and increase guest loyalty.
\end{abstract}

Keywords: service quality, brand attributes, satisfaction, loyalty, Le Meridien Bali Jimbaran

\section{INTRODUCTION}

Le Meridien is a property and brand of the Marriott International company that focuses on a European perspective. This brand started appearing in the 1960's and was used as a place where people got together to enjoy the fun of life. Le Meridien was founded for the first time in Paris which takes local culture into its properties. Le Meridien Bali at Jimbaran is a hotel that compete to attract the tourists come to stay and count on the quality of service and the attributes of the Le Meridien brand which has an advantage compared with other hotels.

Service quality is an important aspect and affects the satisfaction of guests stay- 
ing at a hotel. The more quality services provided by employees at a hotel, the more satisfied the guest is. The level of guest satisfaction will also affect guest loyalty. Tourist satisfaction becomes a marker in determining whether or not the hotel is eligible to be re-chosen by tourists as a place to stay. The satisfaction of the tourists will be achieved when reality exceeds expectations. This tourist satisfaction is able to encourage guests who will be loyal to the hotel. Each hotel is competing to highlight the advantages of the attributes they have in order to attract tourists to come to stay at their hotel.

The guests who stay at Le Meridien Bali at Jimbaran come from various countries. This hotel also has the quality of service and brand attributes that can be offered to guests during their stay. The proliferation of hotels with well-known brands with various prominent attributes, this five-star hotel as one of the hotel chains in Bali also highlights the quality of service and brand attributes it has.

The objectives of this study are as follows: To analyze the effect of service quality and brand attributes on guest satisfaction who stay at the Le Meridien Bali Jimbaran hotel To analyze the effect of service quality and brand attributes on the loyalty of guests staying at the Le Meridien Bali Jimbaran hotel. To analyze the effect of satisfaction on the loyalty of guests staying at the Le Meridien Bali Jimbaran hotel.

\section{LITERATURE REVIEW}

\section{Previous Research}

Previous research is used as a reference by the author as a review material in conducting research. The research entitled "Evaluation of Marketing Strategy of Sanur Village Festival Based on Visitors" Behavior " by Suryawardani and Wiranatha (2018) examines the behavior of tourists to evaluate marketing strategies carried out at the Sanur Festival, Bali which is analyzed by SmartPLS. This study was designed to determine the relationship between revisit intention and planned visits to the Sanur Village Festival and to evaluate marketing strategies based on tourist behavior. This study concludes that tourists' revisit intention is significantly influenced by attitude toward behavior and perceived behavior control, and plan to revisit is significantly influenced by behavior intention and perceived behavior control.

Research on service quality that is used as a reference is written by Purnami and Suryawardani (2018). This study was analyzed using the Structural Equation Modeling (SEM) model with SmartPLS version 3.0. The results of this study indicate that the physical evidence has a significant effect on visitor satisfaction. Reliability has a significant effect on tourist satisfaction. Responsiveness has a significant effect on tourist satisfaction. Assurance has a significant effect on visitor satisfaction. Empathy has a significant effect on visiting satisfaction. Satisfaction has a significant effect on revisit intention. The results of this study expects that the quality of service is maintained and enhanced in Bali Pulina Agrotourism.

Research on brands was conducted by Diarta, Lestari and Dewi (2016), this study examines branding which is an inevitable part of the strategy for product and service sales promotion in the era of globalization. This study concludes that branding is very effective in the promotion of sales of processed agricultural products as used in other manufactured products. Branding can be considered as a promotional medium so that sales become more competitive with other competitors. Similar research on brand variables, service quality and customer satisfaction was also conducted by Zalfa (2019). The results showed that the brand image variable had a positive and significant effect on customer satisfaction. 
Service quality variable has a significant effect on customer satisfaction. Servicescape variable has a significant effect on customer satisfaction. Research by Miteva and Ackovska (2017) also analyzes customer satisfaction and customer loyalty. This study shows that there is a strong relationship between brand positioning and customer perspectives that lead to opportunities for customer satisfaction and loyalty. Research by Al-Msallam (2015) shows that customer satisfaction significantly affects customer loyalty and the factors of brand image and price fairness also affect customer loyalty. Previous research on brand or hotel attributes on guest satisfaction.

This research was conducted by Usta, Berezina and Cobanoglu (2011) with the title "The Impact of Hotel Attributes" Satisfaction on Overall Guest Satisfaction ". This study shows that the hotel attributes perceived by guests are an important factor in predicting guest satisfaction. In addition, the findings of this study indicate that there is a strong relationship between the overall satisfaction of guests staying at the hotel and the intention to return to stay. Previous research that was used as a review related to brand (hotel) attributes on guest loyalty was written by Yusof et al. (2018). The research shows that there is a positive effect of hotel attributes, service performance, and experience quality on hotel brand loyalty. Hotels with facilities, furniture and a comfortable atmosphere as well as entertainment in the hotel also affect hotel brand loyalty.

Another study by Nidyatantri, Suryawardani and Agung (2016) shows that customer satisfaction has a significant effect on customer loyalty of Japanese soybean edamame. Customer trust has a significant effect on loyalty. Customer satisfaction has a significant correlation with customer trust. The results also showed that the indicators of taste, price, coverage, product, promotion, product packaging, and practical effects significantly affected satisfaction.

Similar research on satisfaction and loyalty variables was written by Wiranatha, Bendesa and Suryawardani (2018). This study is designed to assess the level of satisfaction of foreign tourists in visiting Balinese heritage and cultural sites, to identify variables that affect the loyalty of foreign tourists in visiting Balinese heritage and cultural sites, to analyze the relationship between the variables that shape the loyalty of foreign tourists in visiting Balinese cultural heritage sites. This study used accidental sampling with a Likert rating scale. Variables were analyzed with Smart PLS software based on the Structural Equation Model. The results of this study indicate that foreign tourists are mostly satisfied in visiting Balinese cultural heritage sites, the variables that affect the satisfaction of foreign tourists visiting cultural heritage sites are intrinsic and extrinsic motivation, there is a significant relationship between intrinsic variables on trust, intrinsic motivation and tourist satisfaction. extrinsic motivation with trust, and between trust and tourist satisfaction.

Research by Yoga, Suryawardani and Angreni (2016) used Amos 22 and SPSS 22 to analyze data using the Structural Equation Model (SEM). The results of this study indicate that the factors that influence customer trust are image, customer benefits, and honesty. There are factors that affect customer loyalty such as repurchases, word of mouth, and not switching to another brand. Customer satisfaction has a significant relationship with loyalty. Customer satisfaction has a significant correlation with customer trust. Research on tourist loyalty was also carried out by Wiranatha $e t$ al. (2016). This study examines the loyalty of foreign tourists to marine tourism in Bali. Intrinsic motivation has a significant effect on tourists' trust in diving, extrinsic motivation has a significant effect on satis- 
faction. Tourist satisfaction also has a significant effect on guest loyalty.

Research on loyalty was studied by Suryawardani et al. (2017). Using Accidental Sampling technique, AMOS Software Version 3.2.3 was used to analyze Structural Equation Modeling (SEM) in this study. The results showed that intrinsic and extrinsic motivation had an effect on satisfaction through the mediation of the latent variable of trust. Only extrinsic motivation through the mediating variables of trust and satisfaction has a significant effect on the loyalty of foreign tourists to visit nature-based tourism in Bali. The results showed that extrinsic motivation variables such as diversity of tourist objects, natural beauty, unique scenery, Balinese traditions and biodiversity have a significant effect on tourist loyalty in visiting Bali naturebased tourism through the variables of trust and satisfaction. Increasing the quality of destinations is very important to be able to achieve the loyalty of tourists visiting Bali, including accessibility, quality of service, security, comfort, accommodation, food and beverages to create foreign tourists' interest in tourism.

\section{Consumer behavior}

Engel, et al in Sangadji and Sopiah (2013) suggest that consumer behavior is an action that is directly involved in obtaining, and consuming products and services, including the process that precedes the action. Consumer behavior is all activities or actions that encourage these actions before purchasing, when purchasing, using and consuming products and services according to Griffin in Sangadji and Sopiah (2013). According to Hasan (2013) consumer behavior is a process that is involved when individuals or groups choose, buy and use products, services, ideas or experiences to satisfy consumer needs or desires. Meanwhile, Schiffman and Kanuk (2012) state that consumer behavior is an action that is directly involved in obtaining and consuming these products and services, including in the decision process that follows this action. Kotler and Keller (2009) define consumer behavior as a study that examines how individuals and groups and organizations choose, buy, and use goods, services or ideas to satisfy consumer needs and desires. Sunyoto (2012) states that consumer behavior is an activity carried out by individuals either directly involved in obtaining and using goods or services which are included in the decision-making process in preparation for determining these activities. According to the definitions presented by the experts, it can be concluded that consumer behavior is a decision taken by individuals, groups or organizations in obtaining or purchasing a product, service, idea or experience.

\section{Brand}

Brand is a name, sign, symbol or design that is intended to identify goods or services from a single seller or group. Brands are an essential part of all cultures that exist on this planet, as well as in the business world. Brands help in making decisions, be they big or small ones. Brands are the expectations, perceptions, ideas and beliefs that exist in consumers' memories (Kotler, 2010).

\section{Quality of Service}

Service quality according to Parasuraman, Zeithaml and Berry (1988) known as Servqual which consists of five dimensions as follows: Tangibles, which are physical evidence of a company's ability in terms of showing its existence to external parties

Reliability, is the reliability of a company in providing accurate and reliable services. Responsiveness, namely the responsiveness or willingness of a company to help and provide fast and responsive service. Assurance, is a guarantee or certainty from a company in terms of politeness 
and the ability of employees of a company to foster customer trust. Empathy, sincere attention given by individual employees to customers.

\section{Satisfaction}

Satisfaction is the accumulated result of the customer in terms of using a product or service. A good product is a product that makes customers satisfied after buying the product Irawan (2008). Customers who are satisfied with the product or service will recommend or share their experiences with other customers.

The following are indicators of satisfaction which include: Feelings of satisfaction; Always buy a product; Recommend to others; Customer expectations are met after purchasing the product.

\section{Loyalty}

Loyalty is a commitment from consumers to persevere deeply to keep subscribing or repurchasing the selected products or services consistently both now and in the future, even though the situation and marketing efforts have the potential to change Hurriyati (2005) behavior.

\section{Brand Attribute}

Product attributes are divided into three elements, namely product quality (product quality), product features (product features) and product design (product design) which are used as important elements in these product attributes (Kotler and Armstrong, 2004).

\section{METHODS}

\section{Location and Time of Conducting the Research}

This research was conducted at the Le Meridien Bali Jimbaran hotel which is located at Jl. Bukit Permai, Jimbaran, South Kuta District, Badung Regency, Bali 80361. Next to a seafood restaurant in Mu- aya Beach, Jimbaran. Located 7 kilometers from I Gusti Ngurah Rai International Airport and 4.5 kilometers from the Garuda Wisnu Kencana Cultural Park. This research was conducted from January 2020 to March 2020.

\section{Population and Sampling}

The population in this study were guests who stayed at the Le Meridien Bali Jimbaran hotel. In 2019, from January to December there were 105,088 guests staying at the hotel. Determination of the research sample using accidental sampling technique, the sample is determined by accidental, namely whoever the guests the researcher happens to meet can then be used as a suitable sample as a data source.

This sample determination is in accordance with the opinion of Ghozali (2014) who analyzed the data with the student version of the SmartPLS software, which limits the number of samples not to exceed 100 samples.

\section{Research Variables and Indicators}

The variables used in this study are: Latent Variable (Construct), a measure that cannot be measured or is abstract. The latent variable types are as follows: Influential latent variables (exogenous variables) are variables that affect other variables which are marked with the symbol $\mathrm{X}$. The exogenous variables in this study are service quality (X1) and brand attributes (X2).

Influential latent variables (endogenous variables) are variables that are influenced by other variables. In this study, there are two types of latent variables that are influenced, namely latent variables that are influenced by moderating intervening with the symbol Y1 (guest satisfaction) and latent variables which are influenced purely by the symbol Y2 (guest loyalty).

Indicators (manifest), are the elements that form latent variables so that they can be measured. 
Table 1. Deskripsi Operasional Variabel Laten dan Indikator

\begin{tabular}{|c|c|c|c|c|}
\hline $\begin{array}{c}\text { Latent } \\
\text { Variable }\end{array}$ & Indicator & Code & Total & Source \\
\hline $\begin{array}{l}\text { Quality } \\
\text { of Service } \\
\text { (X1) }\end{array}$ & $\begin{array}{l}\text { Good looking employees. Employees have } \\
\text { a reliable ability to handle guests. Employ- } \\
\text { ees are responsive to guest requests. } \\
\text { Employees have the courtesy to work. } \\
\text { Employees at work must have attention dur- } \\
\text { ing guests' stay and must be able to under- } \\
\text { stand the wishes of guests }\end{array}$ & $\begin{array}{l}\mathrm{X} 1.1 \\
\mathrm{X} 1.2 \\
\mathrm{X} 1.3 \\
\mathrm{X} 1.4 \\
\mathrm{X} 1.5\end{array}$ & 5 & $\begin{array}{l}\text { Parasuraman, } \\
2006\end{array}$ \\
\hline $\begin{array}{l}\text { Brand } \\
\text { Attribute } \\
(\mathrm{X} 2)\end{array}$ & $\begin{array}{l}\text { Le Meridien has good quality products } \\
\text { Le Meridien offers products consistently. } \\
\text { The attributes offered by the Le Meridien } \\
\text { Bali Jimbaran hotel are complete. } \\
\text { Le Meridien has guest facilities in an attrac- } \\
\text { tive style. } \\
\text { Le Meridien Bali Jimbaran has a unique } \\
\text { building shape. }\end{array}$ & $\begin{array}{l}\text { X2.1 } \\
\text { X2.2 } \\
\text { X2.3 } \\
\text { X2.4 } \\
\text { X2.5 }\end{array}$ & 5 & $\begin{array}{l}\text { Kotlerand } \\
\text { Amstong, } \\
2004\end{array}$ \\
\hline $\begin{array}{l}\text { Guest Sat- } \\
\text { isfaction } \\
\text { (Y1) }\end{array}$ & $\begin{array}{l}\text { I feel satisfied with the quality products } \\
\text { from Le Meridien Bali Jimbaran. } \\
\text { I feel satisfied with the cleanliness at the Le } \\
\text { Meridien Bali Jimbaran hotel. } \\
\text { I feel satisfied because the products offered } \\
\text { by the Le Meridien Bali Jimbaran hotel } \\
\text { match or even exceed my expectations. } \\
\text { The need to stay at the Le Meridien Bali } \\
\text { Jimbaran hotel is fulfilled. } \\
\text { I will continue to buy the products offered } \\
\text { by Le Meridien Bali Jimbaran. }\end{array}$ & $\begin{array}{l}\text { Y1.1 } \\
\text { Y1.2 } \\
\text { Y1.3 }\end{array}$ & 5 & Irawan, 2008 \\
\hline $\begin{array}{l}\text { Loyalty } \\
\text { (Y2) }\end{array}$ & $\begin{array}{l}\text { I will extend the period of stay at the Le } \\
\text { Meridien Bali Jimbaran hotel. } \\
\text { I will stay again at the Le Meridien Bali } \\
\text { Jimbaran hotel. } \\
\text { I will give positive comments during my } \\
\text { stay at the Le Meridien Bali Jimbaran hotel } \\
\text { both in person and on social media. } \\
\text { I would recommend Le Meridien Bali } \\
\text { Jimbaran hotel to others (colleagues and } \\
\text { family). } \\
\text { I will still choose Le Meridien brand when } \\
\text { compared to } \\
\text { other brands. }\end{array}$ & $\begin{array}{l}\mathrm{Y} 2.1 \\
\mathrm{Y} 2.2 \\
\mathrm{Y} 2.3 \\
\mathrm{Y} 2.4 \\
\mathrm{Y} 2.5\end{array}$ & 5 & $\begin{array}{l}\text { Pitaloka, } \\
2012\end{array}$ \\
\hline Total & & & 20 & \\
\hline
\end{tabular}




\section{Data analysis technique}

An implementation of research requires the existence of methods, ways or tactics as steps that must be followed in solving a problem in order to achieve a goal. The method used in this research is quantitative descriptive method. This study uses SEM (Structural Equation Modeling) techniques with mediation effects using SmartPLS software. Some of the tests carried out are as follows: Evaluation of the Measurement Model (Measurement/Outer Model); Structural Model Evaluation (Structural/Inner Model)

\section{RESULTS AND DISCUSSION}

\section{General Characteristics of Respondents}

The characteristics of hotel guests consist of the purpose of guests staying, gender, member program, the main purpose of choosing Le Meridien Bali Jimbaran as a place to stay and the number of times they have stayed at the Le Meridien Bali Jimbaran hotel. The five characteristics of the respondents refer to the research title. The characteristics of respondents based on the purpose of staying were dominated by the purpose of vacationing as much as $72 \%$, the respondent data based on gender were dominated by male guests with a percentage of $64 \%$, while $56 \%$ for the percentage who dominated the guest members based on the characteristics according to the member program, characteristics based on the purpose of staying with a value of $39 \%$ who chose Le Meridien Bali Jimbaran because the brand they owned was based on the main purpose of choosing Le Meridien Bali Jimbaran and based on the frequency of stay, $84 \%$ of new guests stayed at the Le Meridien Bali Jimbaran hotel for the first time.

\section{Test of the Validity and Reliability of Research Variables}

Validity and reliability tests in this study were conducted on 100 respondents who were guests staying at the Le Meridien Bali Jimbaran hotel. The validity test was done by looking at the value of Convergent Validity and Discriminant Validity. Convergent Validity was tested by looking at the loading factor value of each indicator on each variable. The loading factor value must also meet the requirements, which is above 0.70 . Discriminant Validity was done by comparing the square root of Average Vaariance Extracted ( $\sqrt{A V E}$ ) in each variable with a correlation between variables and other variables.

The Table 2 shows that all variables can be said to be valid or good. This is because all variables have an average above 0.50 and the root average value is higher than the variable correlation value. The table above is another method that can be used to measure Discriminant Validity, namely by comparing the square root of the Average Variance Extracted for each variable with the correlation between variables and other variables in the model.

The reliability test results can be measured from the Cronbach Alpha value and the Composite Reliability value from each variable. Each variable can be said to have a high level of reliability if the Cronbach Alpha value exceeds 0.7 and the Composite Reliability value exceeds 0.7 . The table above shows that the Cronbach Alpha and Composite Reliability values exceed 0.9 , which means that all variables have met good reliability. Based on the results obtained by involving 100 respondents, both Convergent, Discriminant Validity, Cronbach Alpha and Composite Reliability, it can be concluded that the indicators totaling 20 as a measure of the four latent variables are valid and reliable.

\section{Results of the Measurement Model Analysis (Outer Model)}

Analysis of the measurement model (outer model) shows each indicator in ref- 
Table 2. Research Variable Validity Test Results

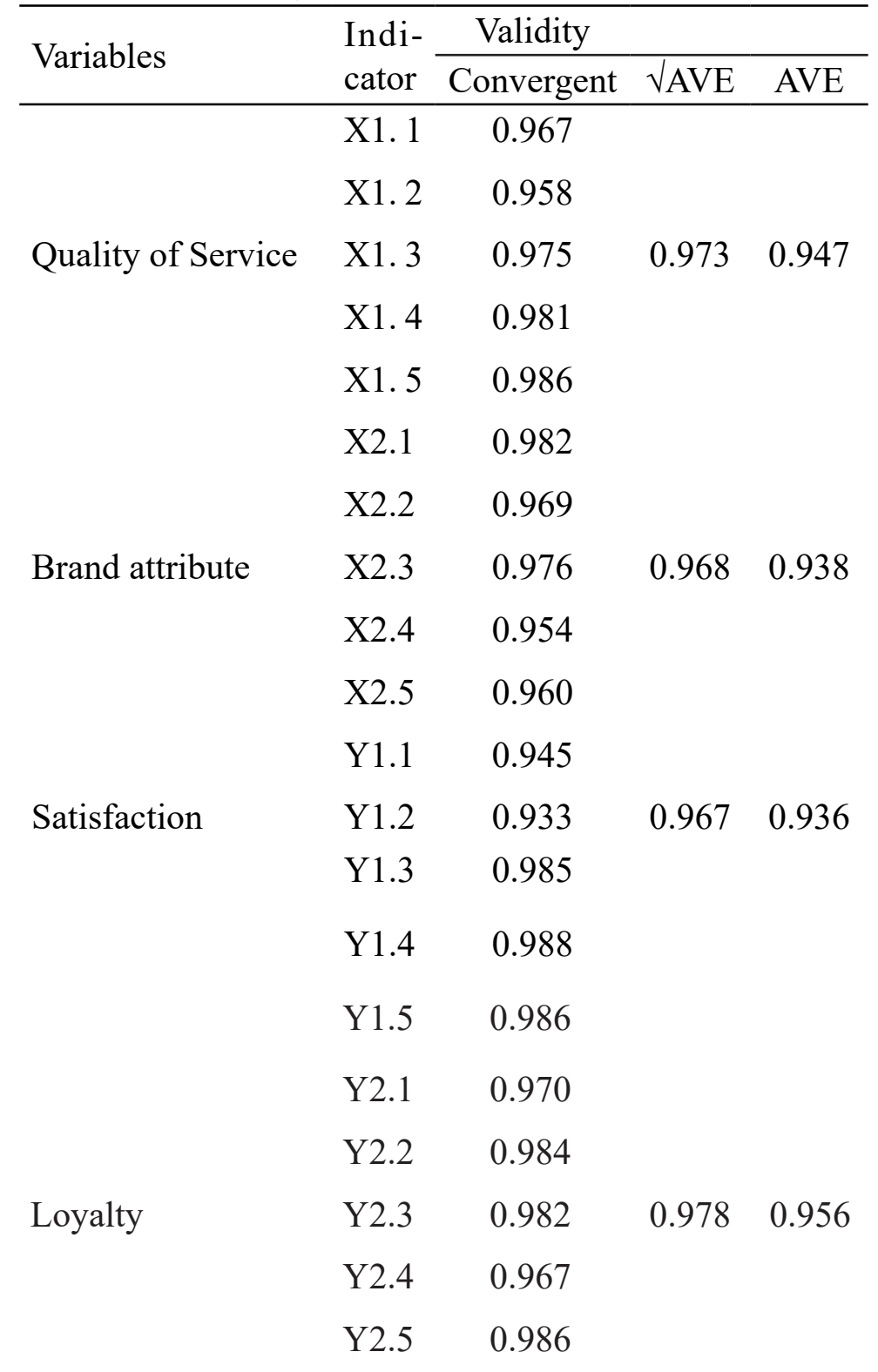

Source: Primary and processed data, 2020

Table 3. Research Variable Reliability Test Results

\begin{tabular}{ccc}
\hline Variable & Cronbach Alpha & Composite Reliability \\
\hline Service quality & 0.986 & 0.989 \\
Brand attribute & 0.983 & 0.987 \\
Satisfaction & 0.983 & 0.987 \\
Loyalty & 0.989 & 0.991 \\
\hline \multicolumn{2}{c}{ Source: Primary and processed data, 2020 }
\end{tabular}

lecting the variables formed by the consti- cance of this relationship can be obtained tuent indicators. This indicator is reflective through a bootstrap process of 500 samples in which the estimated values can be seen with each sample measuring 100 data. from the measurement model. The signifi- 


\section{Test Results of Service Quality Variable Measurement Models}

In accordance with the analysis in the Table 4, it can be seen that one of the indicators, namely Staff have an attention during guest stay and be able to understand the guest needs, has the highest outer loading value compared to other indicators, namely 0.986 . The lowest outer loading value is found in the Staff have strong ability in check in and check out experience indicator, which is 0.958 . This shows that guests who stay at this hotel feel a different quality of service at the Le Meridien Bali Jimbaran hotel.

\section{Test Results of Measurement Model Variable Brand Attributes}

Based on the data Table 5, it can be seen that with the analysis that has been carried out, the Quality of Le Meridien exterior and interior overall indicator has the highest outer model value when compared to other indicators, namely 0.982 . The lowest outer loading value in this variable is Le Meridien Bali Jimbaran pool and lively lobby, which is valued at 0.954 . However, even though it has the lowest outer loading value, this indicator has the highest standard deviation compared to other indicators, namely 0.020 . This shows that the

Table 4. Testing Results of Measurement Models for Service Quality Variables

\begin{tabular}{|c|c|c|c|c|}
\hline Indicator & Statement & $\begin{array}{l}\text { Original } \\
\text { Sample }\end{array}$ & $\begin{array}{c}\text { Standard of } \\
\text { deviation }\end{array}$ & $\begin{array}{c}\mathrm{P} \\
\text { Value }\end{array}$ \\
\hline $\mathrm{X} 1.1 \leftarrow \mathrm{X} 1$ & The Staff service overall & 0.967 & 0.020 & 0.000 \\
\hline $\begin{array}{l}\mathrm{X} 1.2 \leftarrow \\
\mathrm{X} 1\end{array}$ & $\begin{array}{l}\text { Staff have strong ability in check in } \\
\text { and check out experience }\end{array}$ & 0.958 & 0.018 & 0.000 \\
\hline $\begin{array}{l}\mathrm{X} 1.3 \leftarrow \\
\mathrm{X} 1\end{array}$ & Staff have anticipation needs & 0.975 & 0.014 & 0.000 \\
\hline $\begin{array}{l}X 1.4 \leftarrow \\
X 1\end{array}$ & Polite staff in handling guest & 0.981 & 0.010 & 0.000 \\
\hline $\mathrm{X} 1.5 \leftarrow \mathrm{X} 1$ & $\begin{array}{l}\text { Staff have an attention during guest } \\
\text { stay and be able to understand the } \\
\text { guest needs }\end{array}$ & 0.986 & 0.009 & 0.000 \\
\hline
\end{tabular}

Source: Primary and processed data, 2020

Table 5. Test Results of Measurement Model Variable Brand Attributes

\begin{tabular}{|c|c|c|c|c|}
\hline Indicator & Statement & $\begin{array}{l}\text { Original } \\
\text { Sample }\end{array}$ & $\begin{array}{l}\text { Standard } \\
\text { deviation }\end{array}$ & $\begin{array}{c}P \\
\text { Value }\end{array}$ \\
\hline $\mathrm{X} 2.1 \leftarrow \mathrm{X} 2$ & $\begin{array}{l}\text { Quality of Le Meridien exterior and } \\
\text { interior overall }\end{array}$ & 0.982 & 0.007 & 0.000 \\
\hline $\mathrm{X} 2.2 \leftarrow \mathrm{X} 2$ & $\begin{array}{l}\text { Le Meridien Bali Jimbaran offer a } \\
\text { consistency maintenance }\end{array}$ & 0.969 & 0.010 & 0.000 \\
\hline $\mathrm{X} 2.3 \leftarrow \mathrm{X} 2$ & $\begin{array}{l}\text { Le Meridien Bali Jimbaran Public } \\
\text { Space }\end{array}$ & 0.976 & 0.009 & 0.000 \\
\hline $\mathrm{X} 2.4 \leftarrow \mathrm{X} 2$ & $\begin{array}{l}\text { Le Meridien Bali Jimbaran pool and } \\
\text { lively lobby }\end{array}$ & 0.954 & 0.020 & 0.000 \\
\hline $\mathrm{X} 2.5 \leftarrow \mathrm{X} 2$ & $\begin{array}{l}\text { Le Meridien Bali Jimbaran stylist and } \\
\text { up to date design }\end{array}$ & 0.960 & 0.019 & 0.000 \\
\hline
\end{tabular}

Source: Primary and processed data, 2020 
Le Meridien Bali Jimbaran pool and lively lobby can be maintained to become the hallmark of this hotel.

\section{Results of Measurement Model Testing for Satisfaction Variables}

Based on the data analysis Table 6, it can be seen that the indicator I am satisfied of my stay at Le Meridien Bali Jimbaran because fulfilled my need has the highest outer model value, which is 0.988 compa- red to the other four indicators. Meanwhile, the indicator I am satisfied with Le Meridien cleanliness has the lowest outer loading value in this variable, namely 0.933 . However, even though it has the lowest outer model value, this indicator has the highest perceived category with a standard deviation value of A0.021. This shows that Le Meridien Bali Jimbaran has good cleanliness and must be maintained or even improved.

Table 6. Results of Measurement Model Testing for Satisfaction Variables

\begin{tabular}{|c|c|c|c|c|}
\hline Indicator & Statement & $\begin{array}{l}\text { Original } \\
\text { Sample }\end{array}$ & $\begin{array}{l}\text { Standard } \\
\text { deviation }\end{array}$ & $\begin{array}{c}\mathrm{P} \\
\text { Value }\end{array}$ \\
\hline $\mathrm{Y} 1.1 \leftarrow \mathrm{Y} 1$ & $\begin{array}{l}\text { I am satisfied with the Le Meridien } \\
\text { quality of Food\&Beverage }\end{array}$ & 0.945 & 0.016 & 0.000 \\
\hline $\mathrm{Y} 1.2 \leftarrow \mathrm{Y} 1$ & $\begin{array}{l}\text { Iamsatisfiedwith LeMeridien } \\
\text { cleanliness }\end{array}$ & 0.933 & 0.021 & 0.000 \\
\hline $\mathrm{Y} 1.3 \leftarrow \mathrm{Y} 1$ & $\begin{array}{l}\text { I am satisfied with the quality of the at- } \\
\text { tributesthatLeMeridiensell } \\
\text { because it has fulfilled my expectation }\end{array}$ & 0.985 & 0.004 & 0.000 \\
\hline $\mathrm{Y} 1.4 \leftarrow \mathrm{Y} 1$ & $\begin{array}{l}\text { I am satisfied of my stay at Le Meridien } \\
\text { Bali Jimbaran because fulfilled my } \\
\text { need }\end{array}$ & 0.988 & 0.003 & 0.000 \\
\hline $\mathrm{Y} 1.5 \leftarrow \mathrm{Y} 1$ & $\begin{array}{l}\text { I will continue to buy brand attributes } \\
\text { if the desired expectation are achieved }\end{array}$ & 0.986 & 0.004 & 0.000 \\
\hline
\end{tabular}

Source: Primary and processed data, 2020

Table 7. Results of Measurement Model Testing for Loyalty Variables

\begin{tabular}{|c|c|c|c|c|}
\hline Indicator & Statement & $\begin{array}{l}\text { Original } \\
\text { Sample }\end{array}$ & $\begin{array}{l}\text { Standard } \\
\text { deviation }\end{array}$ & P Value \\
\hline $\mathrm{Y} 2.1 \leftarrow \mathrm{Y} 2$ & Le Meridien brand enhance stay & 0.970 & 0.010 & 0.000 \\
\hline \multirow[t]{2}{*}{$\mathrm{Y} 2.2 \leftarrow \mathrm{Y} 2$} & I will stay again at Le Meridien Bali & 0.984 & 0.005 & 0.000 \\
\hline & Jimbaran & & & \\
\hline \multirow[t]{2}{*}{$\mathrm{Y} 2.3 \leftarrow \mathrm{Y} 2$} & $\begin{array}{l}\text { I will give positive feedback or comment } \\
\text { during my stay at Le Meridien Bali Jimba- } \\
\text { ran through social media or directly to the }\end{array}$ & 0.982 & 0.006 & 0.000 \\
\hline & management & & & \\
\hline \multirow[t]{2}{*}{$\mathrm{Y} 2.4 \leftarrow \mathrm{Y} 2$} & Intent to recommend Le Meridien brand to & 0.967 & 0.011 & 0.000 \\
\hline & family or relatives & & & \\
\hline$Y 2.5 \leftarrow Y 2$ & Intent to consider brand & 0.986 & 0.006 & 0.000 \\
\hline
\end{tabular}

Source: Primary and processed data, 2020 


\section{Results of Measurement Model Testing for Loyalty Variables}

Based on the results of the research through the Table 7 , it can be seen that the indicator of Intent to consider a brand has the highest outer model value, namely 0.986 compared to the other four indicators. In the table that has been presented, it can also be seen that the Intent to recommend Le Meridien brand to family or relatives indicator has the lowest outer model value, which is 0.967 . This indicator gets the highest perception, namely 0.011 , which in the future gets the highest perception from guests as respondents compared to other indicators. This shows that the Le Meridien brand makes guests have the desire to recommend it to others.

\section{Results of the Structural Equation Model Analysis (Inner Model)}

Structural model analysis or inner model is carried out to determine the relationship between exogenous variables and endogenous variables which has been the hypothesis of this study.

The Table 8 shows that there are four direct relationships that occur between one variable and another, but there is one variable with other variables for which there is no direct relationship. The results of the direct effect of exogenous variables on endogenous variables are significantly $1 \%$ $(0.01)$, so Ho is rejected if the p-value is $<0.05$, then the statistical results of the study are as follows
H1: Based on the research results, it can be seen that there is a direct influence between service quality and satisfaction with a significant value, namely 0.351 , with the original value until the estimate shows a positive number. Thus the hypothesis Ho is rejected while the hypothesis $\mathrm{Ha}$ is accepted which states that "Service Quality has a significant effect.

$\mathrm{H} 2$ : The results showed that there was no significant direct influence between service and guest loyalty who stayed at the Le Meridien Bali Jimbaran hotel. Ho is accepted because "Service quality does not have a significant effect on loyalty", while Ha is rejected because there is no direct influence between service quality and loyalty. The results showed that there was no significant direct influence between service quality and guest loyalty who stayed at the Le Meridien Bali Jimbaran hotel. Ho is accepted because "Service quality does not have a significant effect on loyalty", while $\mathrm{Ha}$ is rejected because there is no direct influence between service quality and loyalty.

H3: The results show that there is a direct influence with the significant value of the original sample estimate is 0.670 , thus Ho is rejected while $\mathrm{Ha}$ is accepted which states that "Brand attributes have a significant effect on satisfaction.".

H4: The results showed that brand attributes have a significant effect on loyalty with the original sample value positive estimate 0.160 , thus the Ho hypothesis is rejected in this study, while $\mathrm{Ha}$ is accepted

Table 8. Direct Effect of Exogenous Variables on Endogenous Variables

\begin{tabular}{cccccc}
\hline Hypothesis & $\begin{array}{c}\text { Exogenous Variables } \\
\rightarrow \text { Endogenous }\end{array}$ & $\begin{array}{c}\text { Original } \\
\text { Sample (O) }\end{array}$ & $\begin{array}{c}\text { Sample } \\
\text { Mean (M) }\end{array}$ & $\begin{array}{c}\text { Standard } \\
\text { Deviation } \\
(\text { STDEV) }\end{array}$ & P Values \\
\hline $\mathrm{H} 1$ & $\mathrm{X} 1 \rightarrow \mathrm{Y} 1$ & 0.351 & 0.343 & 0.092 & 0.000 \\
$\mathrm{H} 2$ & $\mathrm{X} 1 \rightarrow \mathrm{Y} 2$ & -0.043 & -0.041 & 0.039 & 0.279 \\
$\mathrm{H} 3$ & $\mathrm{X} 2 \rightarrow \mathrm{Y} 1$ & 0.670 & 0.679 & 0.089 & 0.000 \\
$\mathrm{H} 4$ & $\mathrm{X} 2 \rightarrow \mathrm{Y} 2$ & 0.160 & 0.158 & 0.061 & 0.009 \\
$\mathrm{H} 5$ & $\mathrm{Y} 1 \rightarrow \mathrm{Y} 2$ & 0.866 & 0.867 & 0.070 & 0.000 \\
\hline
\end{tabular}

Source: Primary and processed data, 2020

http://ojs.unud.ac.id/index.php/eot 
because the study shows that "brand attributes have a significant effect on loyalty".

H5: Based on the results of the study which shows that the satisfaction variable has a significant effect on loyalty, the original sample value is positive estimate of 0.866 . Ho was rejected while Ha was accepted because "Satisfaction has a significant effect on loyalty".

\section{Indirect Effect}

The results showed that the relationship between service quality and loyalty mediated by satisfaction is significant with a T-statistic of 3,521 ( $>1.96)$. The table above shows that the relationship between service quality and loyalty is significant with the original sample estimate value of 0.304 which indicates that the relationship between service quality and loyalty through satisfaction is influential with ( $p$ value $0.000<0.05$ ).

Furthermore, there is a relationship between brand attributes and loyalty which is mediated by satisfaction with the original sample estimate value is 0.580 . Based on the results of the study, it shows that the relationship between brand attribute and loyalty mediated by satisfaction is significant with a T-statistic of $6,860(>1.96)$. This shows that the direction of the relationship between brand attribute and loyalty with mediation of satisfaction has a significant effect on value ( $p$ value $0.000<0.05$ ).

\section{Total Effect}

Based on the Table 10, it can be concluded that the total effect that occurs from the relationship between exogenous variables and endogenous variables. The table above shows that satisfaction with loyalty has the greatest influence, namely 0.866 . So it can be concluded that satisfaction has a dominant effect in creating guest loyalty when staying at the Le Meridien Bali Jimbaran hotel.

\section{Result of Feasibility Analysis of Struc- tural Equation Model}

The $\mathrm{R}$ square value of the satisfaction variable is 0.877 , this shows that the model with endogenous variables of satisfaction has predictive power in the strong category. While the $\mathrm{R}$ square value of the loyalty variable is 0.960 , indicating that it has predictive power in the strong category. The feasibility of a structural equation model as a whole or calculating the goodness of fit (GOF) value of the model can be done by referring to the formula introduced by Te-

Table 9. Indirect Effect of Exogenous Variables on Endogenous Variables

\begin{tabular}{ccccc}
\hline $\begin{array}{c}\text { Exogenous Variables } \rightarrow \\
\text { Endogenous Var. }\end{array}$ & $\begin{array}{c}\text { Original } \\
\text { Sample }(\mathrm{O})\end{array}$ & $\begin{array}{c}\text { Sample Mean } \\
(\mathrm{M})\end{array}$ & $\begin{array}{c}\text { Standard Deviation } \\
(\text { STDEV) }\end{array}$ & P-Values \\
\hline $\mathrm{X} 1 \rightarrow \mathrm{Y} 1 \rightarrow \mathrm{Y} 2$ & 0.304 & 0.298 & 0.086 & 0.000 \\
$\mathrm{X} 2 \rightarrow \mathrm{Y} 1 \rightarrow \mathrm{Y} 2$ & 0.580 & 0.587 & 0.085 & 0.000 \\
\hline
\end{tabular}

Source: 2020 Primary Data, (Attachment 4)

Table 10. Effect of Total Exogenous Variables on Endogenous Variables

\begin{tabular}{ccccc}
\hline $\begin{array}{c}\text { Exogenous Variables } \rightarrow \\
\text { Endogenous Variables }\end{array}$ & $\begin{array}{c}\text { Original } \\
\text { Sample }(\mathrm{O})\end{array}$ & $\begin{array}{c}\text { Sample } \\
\text { Mean }(\mathrm{M})\end{array}$ & $\begin{array}{c}\text { Standard Deviation } \\
(\mathrm{STDEV})\end{array}$ & P Values \\
\hline $\mathrm{X} 1 \rightarrow \mathrm{Y} 1$ & 0.351 & 0.343 & 0.092 & 0.000 \\
$\mathrm{X} 1 \rightarrow \mathrm{Y} 2$ & 0.261 & 0.257 & 0.089 & 0.003 \\
$\mathrm{X} 2 \rightarrow \mathrm{Y} 1$ & 0.670 & 0.679 & 0.089 & 0.000 \\
$\mathrm{X} 2 \rightarrow \mathrm{Y} 2$ & 0.741 & 0.745 & 0.080 & 0.000 \\
$\mathrm{Y} 1 \rightarrow$ Y2 & 0.866 & 0.867 & 0.070 & 0.000 \\
\hline
\end{tabular}

Source: Primary and processed data, 2020 
nenhaus et al (2005) as follows:

$$
\text { Gof }=\sqrt{ } \operatorname{Com} x R^{2}=\sqrt{ } A V E x R^{2}
$$

Referring to the equation table above, AVE is a weighted average value with the weight obtained from the number of indicators for each variable. Using this formula, the GoF of the model is calculated as 0.603 with a size that exceeds the 0.50 threshold to state that the model can be accepted and interpreted, so that the analysis can be continued.

The goodness of fit test of the structural equation model can also be seen from the SRMR value of the model. The structural equation model is declared to have met the Goodness of Fit criteria of the model if the SMRM value is $<0.1$ and the model is declared perfect fit if the SRMR value $<0.08$. The results of the goodness of fit test for the structure equation model in the table below show that the SRMR value of the PLS model is 0.024. Because the SRMR model value is below 0.08 , the PLS model is declared perfect fit so it is very feasible to be used to test the research hypothesis.

\section{Confirmative Analysis}

Confirmative analysis in this study is shown to attract infrastructure related to the influence of service quality and brand attributes on satisfaction and loyalty. Through the Structural Equation Model (SEM) equation model which involves four variables, namely service quality, brand satisfaction and loyalty attributes. The output of the structural equation model developed after the analysis through the algorithmic process can be seen in the Table 12 .

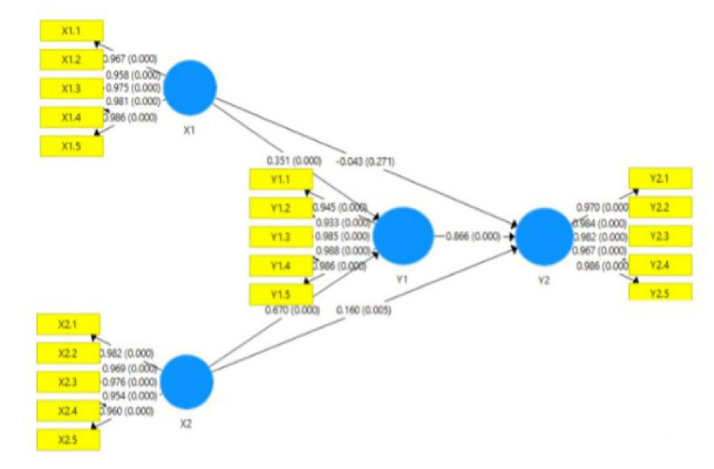

Figure 1. Output of Structural Equation Model The Effect of Service Quality and Brand Attributes on Satisfaction and Loyalty.

Table 11. Feasibility Statistics Value of Research Variables

\begin{tabular}{ccccc}
\hline Variables & Variable Type & $\begin{array}{c}\text { Composite } \\
\text { Reliability }\end{array}$ & AVE & $\left(\mathrm{R}^{2}\right)$ \\
\hline Quality of Service & Exogenous & 0.989 & 0.947 & - \\
Brand attribute & Exogenous & 0.987 & 0.983 & - \\
Satisfaction & Exogenous /Endogenous & 0.987 & 0.936 & 0.877 \\
Loyalty & Endogenous & 0.991 & 0.956 & 0.960 \\
\hline
\end{tabular}

Source: Primary and processed data, 2020

Table 12. Goodness of Fit Test Result of Research Model

\begin{tabular}{ccc}
\hline & Saturated model & Estimate model \\
\hline SRMR & 0.024 & 0.024 \\
D_ULS & 0.123 & 0.123 \\
D_G & 1.503 & 1.503 \\
Chi_square & 650.871 & 650.871 \\
NFI & 0.872 & 0.872 \\
\hline
\end{tabular}

Source: Primary and processed data, 2020 
This study aims to determine the effect of Service Quality and Brand Attributes on the satisfaction and loyalty of guests staying at the Le Meridien Bali Jimbaran hotel. This section will discuss the results of calculations that have been carried out based on the results of the PLS analysis. Testing was done through hypotheses that have been proposed so that we can find out the effect of each variable on the other variables.

\section{Effect of Service Quality on Satisfaction}

Based on the results of the PLS analysis, it shows that service quality has a significant effect on satisfaction (path coefficient of 0.351 with a t-statistic value of 3,814 ) so that the analysis of the results of this research model shows that good service quality will tend to increase guest satisfaction staying at the Le Meridien Bali hotel Jimbaran. Indirectly or directly, good service quality will be directly proportional to the level of guest satisfaction. Star hotels do not necessarily show that the hotel is able to make the guests staying at the hotel feel satisfied, but when the quality of service has been created properly, it will be able to make these guests satisfied when staying at the hotel.

This is supported by guest comments when conducting interviews, "all the staff were really nice and helpful, the bedroom was clean". This comment was conveyed by a guest named Cynthia Lim during an interview in the hotel lobby. This guest also said that during her five-night stay at the Le Meridien Bali Jimbaran hotel, she was satisfied with the quality of service provided by the hotel employees. Cynthia Lim also said that, there are many star hotels with good service quality to guests, but she said that "the personalize of the staff make our stay is memorable", guests feel very special because guests feel special. The service quality variable is in accordance with the results of research with processed data sho- wing that the lowest outer loading value is found in the indicator Staff have strong ability in check in and check out experience, namely 0.958 . The five indicators that have been used show that employees in overcoming check-in and check-out are the lowest because when checking in and checking out guests have their own expectations that they don't get during the process.

\section{The Effect of Service Quality on Loyalty}

The results of the analysis in this study indicate that there is no significant effect of service quality on loyalty (path coefficient of -0.043 with a t-statistics value of 1.085). This research, which was conducted at the Le Meridien Bali Jimbaran hotel, did not produce positive results between the influence of service quality on loyalty. Each star hotel has special standards in terms of service quality so as to create guest satisfaction. However, the quality of a hotel service is not a reason for guests to be loyal guests. There are other reasons why these guests become loyal guests. Mainly hotels in Bali where the quality of service provided by the employees of each hotel is no longer in doubt. So that guests have the perception that every hotel in Bali provides good quality service. This is what causes the quality of service not to cause these guests to become loyal guests.

This study shows that there is no direct influence of service quality variables on loyalty as evidenced by the existence of deep conversations with hotel employees, Febrika Aini (Loyalty Manager). Febrika Aini stated that most of the loyal guests of the Le Meridien Bali Jimbaran hotel became loyal guests due to the brand attributes of this hotel. There are also many positive comments through social media related to hotel maintenance, hotel design, hotel location and so on. However, there are not many loyal guests because they want to get good quality service from employees, guests already expect that star hotels have 
good service quality. This is also supported by the location of the Le Meridien hotel in Bali where greeting, service with a smile and a warm welcome are easily found in almost all hotels in Bali.

\section{The Influence of Brand Attributes on Satisfaction}

The results of the analysis using smart PLS show that brand attributes have a significant effect on guest satisfaction staying at the Le Meridien Bali Jimbaran hotel; loyalty (path coefficient of 0.670 with a t-statistics value of 7.499). These results indicate that the Le Meridien Bali Jimbaran hotel brand attributes lead to guest satisfaction. It was also found that $39 \%$ of guests chose to stay at the Le Meridien Bali Jimbaran hotel due to the hotel's brand, beating out four other things, namely price, member level, location and others. A total of 39 guests who have filled out the questionnaire have high expectations of the brand attributes of this hotel, so they chose the main reason to stay at this hotel. After doing the research, it turned out that the brand attributes of this hotel that were expressed by the guests were able to be remembered in the memories of the guests, causing them to become loyal guests. Quality of Le Meridien exterior and interior overall, Le Meridien Bali Jimbaran offer a consistency maintenance, Le Meridien Bali Jimbaran Public Space, Le Meridien Bali Jimbaran pool and lively lobby and Le Meridien Bali Jimbaran stylist and up to date design can create a memorable experience for these guests . Guest satisfaction can be measured if it exceeds expectations, so what guests get exceeds the guests' expectations.

The same thing was also supported by a guest comment during a short interview, "The stay was absolutelly great and we enjoyed a luxury stay" said a guest named Saxena, "we enjoyed the salt water lagoon with the beautifull design, nice taste illy coffee and great. eye opener that I never enjoyed in any other hotel before "furthermore the guest also said that she is a guest who lives in Europe feeling the atmosphere of a mix between Europe and Bali in this hotel" we live in France, and we feel like home here with natural design, Balinese feel and the aculturation especially the statues, food, beverage and our up to date room design ". Guests also said that they were very satisfied with the brand attributes of this hotel which were not only displayed on social media but actually guests found at this hotel. Saxena's favorite brand attribute is Public Space which makes guests very comfortable and satisfied at this hotel.

\section{The Influence of Brand Attributes on Loyalty}

The results of data analysis using smart PLS statistically show that brand attributes have a significant effect on loyalty (path coefficient of 0.160 with a t-statistical value of 2.615) so that the analysis of this research model shows that adequate brand attributes and according to brand standards will lead to on high loyalty. The more adequate the existing brand attributes and what guests expect, the more loyal guests stay, so that the guests will become loyal guests and will come to stay back at the hotel. The short interview process with a guest at that time also supported the strong influence between brand attributes and guest loyalty. A guest named Rian who stated that " We stayed in the hotel for 2 days. Hotel location was nice and quite which I love. My kids went to the kids club and enjoyed it. It had a new Nintendo switch, plenty of options for toys, nice and clean. This guest also said that the interior design of the room was very interesting. "Room was very spacious with a balcony facing the pools or garden".

\section{The Effect of Satisfaction on Loyalty}

The result of statistical analysis shows that satisfaction has a significant effect on the path coefficient of loyalty of 
0.866 with a t-statistical value of 12.368 ). This shows that the more satisfied guests are when staying at the hotel, the more likely it is to create loyal guests so that these guests will recommend the hotel and will come back to stay. The guest characteristics also show that a total of 16 guests also became loyal guests by staying not for the first time in the research period.

An interview was also conducted to strengthen this research with one guest named Farah, this guest stated that this hotel is good and clean, guests are also satisfied with the facilities at this hotel so they will recommend this hotel to their colleagues and will come back to stay at this hotel.

\section{Effect of Service Quality on Loyalty Mediated by Satisfaction}

The processed research results also show the influence of service quality on guest loyalty mediated by satisfaction. Quality of service mediated by satisfaction can create loyal guests. As conveyed by one guest named Bejimekki who said that "This is a beautiful clean hotel offering royal service, the staff is attentive and very pleasant. We were just fine. I highly recommend "with the mediation of satisfaction where guests are satisfied with the quality of service provided by employees, thus causing these guests to recommend this hotel either through social media or directly to their friends and family. In addition, the royal service received by guests during their stay made an extraordinary experience for these guests and causes guests to be satisfied when staying at this hotel.

\section{The Influence of Brand Attributes on Loyalty Mediated by Satisfaction}

Another finding is the influence of brand attributes on loyalty that is mediated by satisfaction. This interesting thing shows that guest loyalty will increase if the guest is satisfied with the brand attributes of this hotel. This result is also supported by interviews conducted with the same guest, namely Bejimekki, who stated that the facilities at this hotel were very adequate and in accordance with what guests expected. "Hotel attribute offer something new to create memorable, my very first time seen lively lobby with mix Balinese and European style and spacious lagoon, I feel satisfied with LM attribute brand". As previously stated, this hotel is a clean hotel, and guests feel very comfortable and satisfied with the facilities of this hotel. Guests are also Le Meridien members so guests are satisfied with the LM brand attribute. This creates a new experience for guests that make these guests feel satisfied so that they will come to stay back at this hotel and provide positive comments to the management.

\section{CONCLUSIONS}

Based on the results of research and discussion on the Effect of Service Quality and Brand Attributes on the Satisfaction and Loyalty of Guests Staying at Le Meridien Hotel Bali Jimbaran, it can be concluded as follows: There is a significant effect of service quality on guest satisfaction who stays at the Le Meridien Bali Jimbaran hotel; There is no significant effect of service quality on loyalty; There is a significant effect of brand attributes on guest satisfaction. The more guests' expectations are met, especially for hotel brands, the more satisfied hotel guests are; There is a significant effect of brand attributes on loyalty. Le Meridien Bali Jimbaran hotel brand attributes are able to make guests loyal by recommending this hotel and having the desire to come back to stay at the Le Meridien Bali Jimbaran hotel; There is a significant effect of satisfaction on loyalty. Satisfied guests will then be able to create strong memories and direct these guests to become loyal guests. 


\section{REFERENCES}

Al-Msallam, S. (2015) 'Customer satisfaction and brand loyalty in the hotel industry', European Scientific Journal.

Diarta, I. K. S., Lestari, P. W. and Dewi, I. A. P. C. (2016) 'Strategi Branding dalam Promosi Penjualan Produk Pertanian Olahan PT. Hatten Bali untuk Pasar Pariwisata Indonesia', Jurnal Manajemen Agribisnis (Journal of Agribusiness Management), 4(2).

Ghozali, I. (2014) Structural Equation Modeling Metode Alternatif dengan Partial Least Square Aplikasi. 4th edn. Semarang: Penerbit: Universitas Diponogoro.

Hasan, A. (2013) 'Marketing dan kasuskasus pilihan'.

Hurriyati, R. (2005) 'Bauran pemasaran \& loyalitas konsumen', Bandung: Alfabeta.

Irawan, H. (2008) 'Sepuluh prinsip kepuasan pelanggan', Jakarta. Penerbit Elex Media Komputindo Kelompok Gramedia.

Kotler and Armstrong, G. (2004) Marketing management: Analysis Planning, Implementation and Control. 10 th Edit. Pearson Education.

Kotler, P. (2010) 'Manajemen Pemasaran, Edisi tiga belas Bahasa Indonesia'. Jilid.

Kotler, P. and Keller, K. L. (2009) 'Manajemen Pemasaran, Jakarta: Erlangga', Laksana. Terjemahan Fajar.

Miteva, N. and Ackovska, M. (2017) 'The impact of hotel chains on the customer satisfaction and loyalty', in International Scientific Conference on Economics and Management EMAN. Association of Economics and Managers of the Balkans, Belgrade, Serbia, pp.

http://ojs.unud.ac.id/index.php/eot
856-861.

Nidyatantri, N. M. M., Suryawardani, I. G. A. O. and Agung, D. G. (2016) 'Pengaruh kepuasan dan kepercayaan terhadap loyalitas konsumen kedelai jepang edamame pendekatan Structural Equation Modeling', Jurnal Agribisnis dan Agrowisata (Journal of Agribusiness and Agritourism).

Parasuraman, A., Zeithaml, V. A. and Berry, L. L. (1988) 'Servqual: A multipleitem scale for measuring consumer perc', Journal of Retailing, 64(1), p. 12.

Purnami, A. and Suryawardani, I. G. A. O. (2018) 'The effect of the Quality Services on the Visitors' Satisfaction and Desire to Pay a Revisit to the Bali Pulina Agrotourism', E-Journal of Tourism, 5(2), pp. 62-71.

Sangadji, E. M. and Sopiah (2013) Perilaku Konsumen Pendekatan Praktis. Yogyakarta: Andi.

Schiffman, L. G. and Kanuk, L. L. (2012) 'Consumer Behaviour'. USA: New Jersey Prentice Hall.

Sunyoto, D. (2012) 'Manajemen Sumber Daya Manusia'. Jakarta: PT Buku Seru.

Suryawardani, I. A. A. O. and Wiranatha, A. S. (2018) 'Evaluation of Marketing Strategy of Sanur Village Festival Based on Visitors" Behaviour', Global and Stochastics Analysis, 6(7).

Suryawardani, I. G. A. O. et al. (2017) 'A Structural Model of Foreign Tourists' Loyalty in Nature-based Tourism in Bali', International Journal of Applied Business and Economic Research, 15(9), pp. 195-215.

Usta, M., Berezina, K. and Cobanoglu, C. (2011) 'The impact of hotel attributes' satisfaction on overall guest satisface-ISSN 2407-392X. p-ISSN 2541-0857 
tion'.

Wiranatha, A. S. et al. (2016) 'Model of Foreign Tourist's Loyalty on Marine Tourism to Visit Bali", International Journal of Multidiciplinary Education Research, 5(3), pp. 1-16.

Wiranatha, A. S., Bendesa, I. K. G. and Suryawardani, I. G. A. O. (2018) 'Model of Foreign Tourists' Loyalty in Cultural and Heritage Tourism in Bali', Global Stochastic Analysis, 5(8), pp. 73-94.

Yoga, I. P. B. S. A., Suryawardani, I. G. A. O. and Angreni, I. G. A. A. L. (2016) 'Hubungan Kepuasan dan Kepercayaan terhadap Loyalitas Konsumen
Kopi Bubuk Cap Mutiara Pendekatan Structural Equation Modeling', Journal of Agribusiness and Agritourism, p. 44932.

Yusof, J. M. et al. (2018) 'Examining the Effects of Service Performance, Hotel Attributes and Experiential Quality on Brand Loyalty: The Case of Hotel Impiana Morib', International Journal of Academic Research in Business And Social Sciences, 8(11), pp. 2075-2085.

Zalfa, A. A. (2019) 'Pengaruh Brand Image, Service Quality, Dan Servicescape Terhadap Customer Satisfaction Hotel Asia Group Di Surakarta'. Universitas Muhammadiyah Surakarta. 